\title{
SIGNIFICANCE OF ARGININE RADICALS FOR STURGEON GONADOTROPIN SECONDARY STRUCTURE AND FUNCTION
}

\author{
Henriks Zenkevičs*, Ilze Vosekalna**, and Vija Vose* \\ *Institute of Biology, University of Latvia, Miera iela 3, Salaspils, LV-2169, LATVIA; \\ E-mail: zenkevics@email.lubi.edu.Iv \\ ${ }^{* *}$ Latvian Institute of Organic Synthesis, Aizkraukles iela 21, Rīga, LV-1006, LATVIA
}

Contributed by Henriks Zenkevičs

\begin{abstract}
Guanidine groups of arginine side chains were selectively chemically modified with 1,2-cyclohexanedione (CHD) in sturgeon (Acipenser güldenstädti Br.) gonadotropic hormone $(G T H)$ and in its subunits. It was found that only two of the six guanidines were accessible for the reagent and each of the two modified groups was bound to an individual subunit. The results showed that both modified groups were located on the surface of the hormone dimeric molecule. $C D$-spectroscopy of the modified hormonal preparations did not indicate any considerable changes in their secondary structure. On the basis of the data obtained, a conclusion was made that the free guanidine groups are of exclusive importance for the hormone function at the receptor level as the bearers of the positive charge in the functionally important active sites or effector zones located on the surface of the hormone molecule. Also, it was shown that the guanidine groups played a certain role in sustaining the functionally effective spatial structure of the subunits and GTH.
\end{abstract}

Key words: fish gonadotropic hormone, subunits, site specific chemical modification, $C D$ spectroscopy, biological function.

\section{INTRODUCTION}

Sturgeon fish (Acipenser güldenstädti Br.) gonadotropic hormone is a glycoprotein and its molecule $(26 \mathrm{kDa})$, like mammalian gonadotropin molecules, is built of two heterodimeric subunits non-covalently bound to each other. Individual subunits have no hormonal function. Hormonal function typical of gonadotropic hormone (GTH) may be restored to about $70 \%$ and immunoreactivity up to $100 \%$ only after in vitro self-reassociation of the separate counterpart subunits into heterodimeric $\alpha-\beta$ molecular structure (Зенкевич, 1994). The hormone contains up to $30 \%$ of the sugar moiety (Зенкевич и др., 1992).

Amino acid analysis has indicated six arginine residues in the hormone molecule, four of which were located in the $\alpha$ subunit $(\alpha \mathrm{GTH})$ and two in the $\beta$ subunit $(\beta \mathrm{GTH})$ (Зенкевич и др., 1985).

It is known that the guanidine groups of the arginine side chains are the carriers of positive charge of protein molecules and may exhibit even stronger basic properties than the amino groups of lysine or the imidazole radicals of histidine. Also, arginine has a rather long side chain, which may also play a certain role in the structural-functional properties of the hormone.
Results of our earlier studies showed that $\beta G T H$, due to its high conformational rigidity ( six $\mathrm{S}-\mathrm{S}$-bonds), serves as a core of the hormone heterodimeric molecule and may impart receptor-specific three-dimensional spatial structure, not only to the conformationally flexible $\alpha \mathrm{GTH}$ (one S-S-bond), but also to the whole $\alpha-\beta$ molecule (Зенкевич и др., 1985; Зенкевич, 1992). However, the role of the guanidine groups in structural-functional properties of the hormone molecule has so far remained unclear. It was shown that the blockage of positive charge of guanidines with a group specific reagent produced a certain shift in the positive charge distribution on the surface of the separate subunits and GTH (Zenkevics et al., 2006). However, the role of the guanidine groups in the maintenance of the functionally effective spatial structure of the hormone has not been investigated. The elucidation of this question was the goal of this study.

\section{MATERIALS AND METHODS}

A highly purified standard preparation of sturgeon GTH was isolated from acetone- dried pituitary glands of the fish using gel-filtration and ion-exchange chromatography on DEAE-cellulose columns, according to the procedure described earlier (Зенкевич, 1992). 
Individual $\alpha$ and $\beta$ subunits of GTH were isolated by ion-exchange chromatography on SE-Sephadex C-25 in $0.025 \mathrm{M}$ acetate buffer at $\mathrm{pH} 4.9$, after GTH dissociation in $8 \mathrm{M}$ urea according to Hennen et al., 1971. Reassociation of subunits was carried out in saline $(12 \mathrm{~h})$ at room temperature at a total protein concentration of about $0.2 \%$, using counterpart subunits at an equimolar ratio.

Double immunodiffusion tests in $1 \%$ agar gel (Bacto-agar Difco, USA) in veronal buffer (ionic strength 0.05, $\mathrm{pH} 8.6$ ) were performed by Ouchterlony's method (Ouchterlony, 1958) using polyclonal monovalent antisera. To produce antisera against GTH and its separate subunits young rabbits were injected with the preparations $(0.2 \mathrm{mg} /$ injection $)$ in saline using complete Freund's adjuvant (Calbiochem, USA) for ten weeks. The relative immunoreactivity as a percent of the standard and modified preparations was calculated as the inverse proportion between the numbers of active double dilutions of the comparatively tested antigens.

Hormonal (gonadotropic) activity of GTH and reassociated (recombined) $\alpha-\beta$ subunit preparations was evaluated using the grass frog Rana temporaria L. oocyte in vitro maturation test (Thornton, 1971). The gonadotropic activity was expressed as the minimal dose of the hormone preparation that produced $50 \%$ test-oocyte maturation $\left(\mathrm{D}_{50}\right)$ (Zenkevics et al., 2005)

The arginine residues in the dimeric GTH molecule and in the individual subunits were modified in the absence of denaturing agent by 1,2-cyclohexanedione (CHD) (ACROS Organics, Belgium), which is known to selectively modify guanidine groups of proteins (Patty and Smith, 1975). The reaction was performed in a borate buffer $(\mathrm{pH} 8.5)$ at a 15fold molar excess of the reagent. The number of modified arginine residues was determined by analyzing the amino acid content (Mikrotehna Praha, Czech Rep.).

Circular dichroism (CD) spectra were recorded on a Jasco J-710 spectropolarimeter over the wavelength range from 180 to $300 \mathrm{~nm}$ at $22-25^{\circ} \mathrm{C}$. The spectropolarimeter was calibrated using epiandrosterone and 10-camphorsulphonic acid as standards. For recording of spectra, $0.1-0.01 \mathrm{~cm}$ quartz cells of Helma were used. The concentration of proteins in the solution was $10^{-3}-10^{-4} \mathrm{M}$. CD data are given in units of molar ellipticity per amino acid residue of an average relative molecular mass 108 . The content of various secondary structures in the preparations was calculated with using the CDPro - CONTINLL software (Sreerama et al., 1999; Witmore and Wallace, 2004; Lees et al., 2006). In our case, CD spectra of 29-48 proteins were used for calculation of the secondary structure elements. The difference between experimental and calculated results varies by about $3-5 \%$.

\section{RESULTS}

The results showed that, in the initial dimeric molecule of the hormone, only two of the six guanidine groups of ar- ginine underwent modification. When separate subunits were used, the degree of modification (i.e., the number of groups modified by the reagent) did not increase, and only one arginine residue was accessible for modification in each individual subunit.

Comparative assessment of the specific gonadotropic function of the reassociated hybrid $\alpha-\beta$ dimers (recombinants) containing one or both CHD-modified subunits using intact GTH as a Standard, revealed that the blockage of one or both guanidines completely inactivates $\alpha-\beta$ structure. Also, CDH-modified standard GTH turned out to be completely devoid of hormonal function.

Comparative immunotests in double diffusion with homologous antisera showed that the immunoreactivity of the hybrid dimers and CHD-GTH decreased on average by $43 \%$ (Table 1). CHD- $\alpha$ GTH did not lower its immunoreactivity while the activity of the CHD- $\beta$ GTH decreased by $22 \%$ in comparison with that of the standard subunit (Table 1). Nevertheless, all the CHD-modified preparations (Table 1) revealed immunologic identity with the corresponding intact standard preparations in the double diffusion reactions using antisera raised against the standards.

CD spectra of the standard GTH and CHD-GTH, $\alpha$ GTH and CHD- $\alpha \mathrm{GTH}$, and $\beta \mathrm{GTH}$ and CHD- $\beta$ GHT are shown in Fig. 1 (A, B and C). A negative band around 193-197 nm and a shoulder (or two minor negative bands) at 205 and $215 \mathrm{~nm}$ are well expressed for GTH, $\alpha$ and $\beta \mathrm{GTH}$, and CHD- $\beta$ GTH. The shape of the curves is different for CHD-GTH and CHD- $\alpha$ GTH. A negative band around 195 $\mathrm{nm}$ dissapears completely for CHD-GTH, but is more expressed in CHD- $\alpha \mathrm{GTH}$.

In the case of $\alpha \mathrm{GTH}$, the negative Cotton effect around 195 $\mathrm{nm}$ is close to the well known negative band of the random coil at $198 \mathrm{~nm}$; while the shoulder and the negative band (around 205 and $215 \mathrm{~nm}$ ) could arise from the significant contribution of the $\beta$-structures, influenced by a minor amount of $\alpha$-helix (Lees et al., 2006).

Table 1

IMMUNOREACTIVITY OF STANDARD AND CHD-MODIFIED PREPARATIONS OF STURGEON GONADOTROPIN

\begin{tabular}{lccc}
\hline \multicolumn{1}{c|}{ Preparation } & Antiserum & Immunoreactivity, \\
\hline GTH (standard ) & GTH & 100 \\
CHD-GTH & GTH & 57 \\
$\alpha$ GTH+ $\beta$ GTH & GTH & 100 \\
CHD- $\alpha$ GTH+CHD- $\beta$ GTH & GTH & 57 \\
CHD- $\alpha$ GTH+ $\beta$ GTH & GTH & 57 \\
$\alpha$ GTH+CHD- $\alpha$ GTH & GTH & 57 \\
$\alpha$ GTH(standard) & $\alpha G T H$ & 100 \\
CHD- $\alpha$ GTH & $\alpha G T H$ & 100 \\
$\beta G T H($ standard) & $\beta G T H$ & 100 \\
CHD- $\beta$ GTH & $\beta G T H$ & 78
\end{tabular}

CHD, modified with 1,2-cyclohexanedione; GTH, gonadotropic hormone 
A

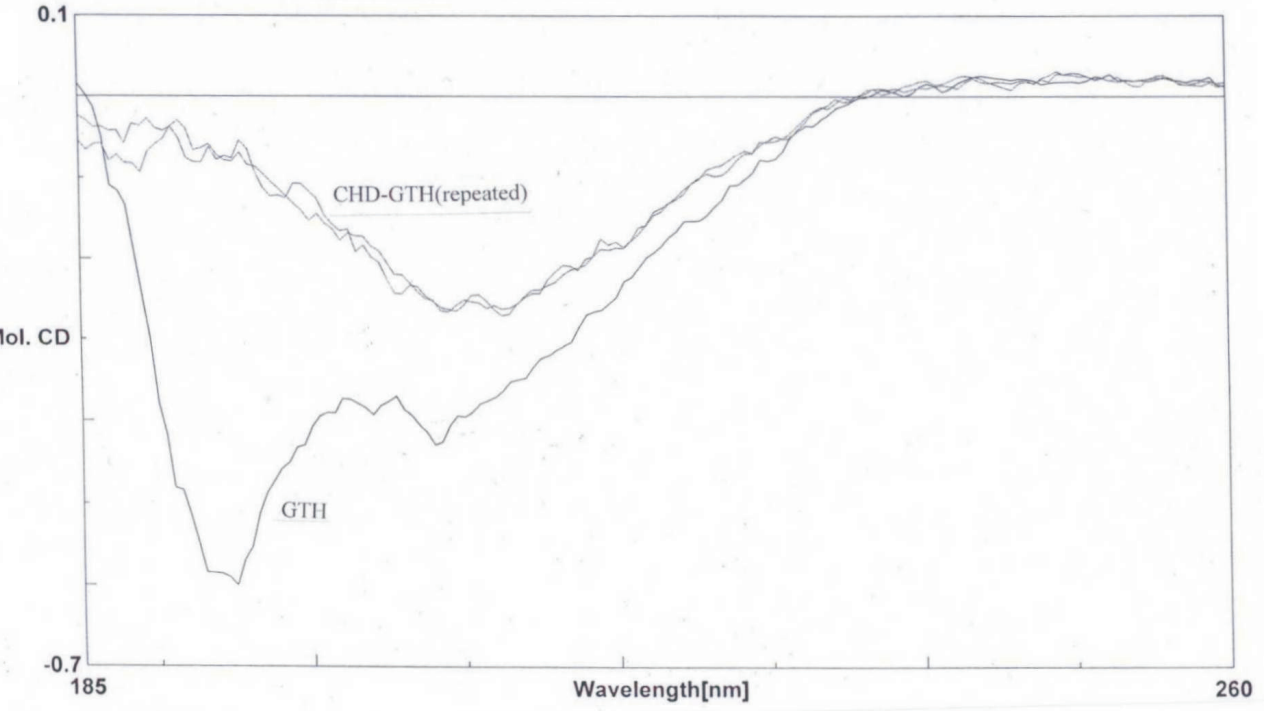

B

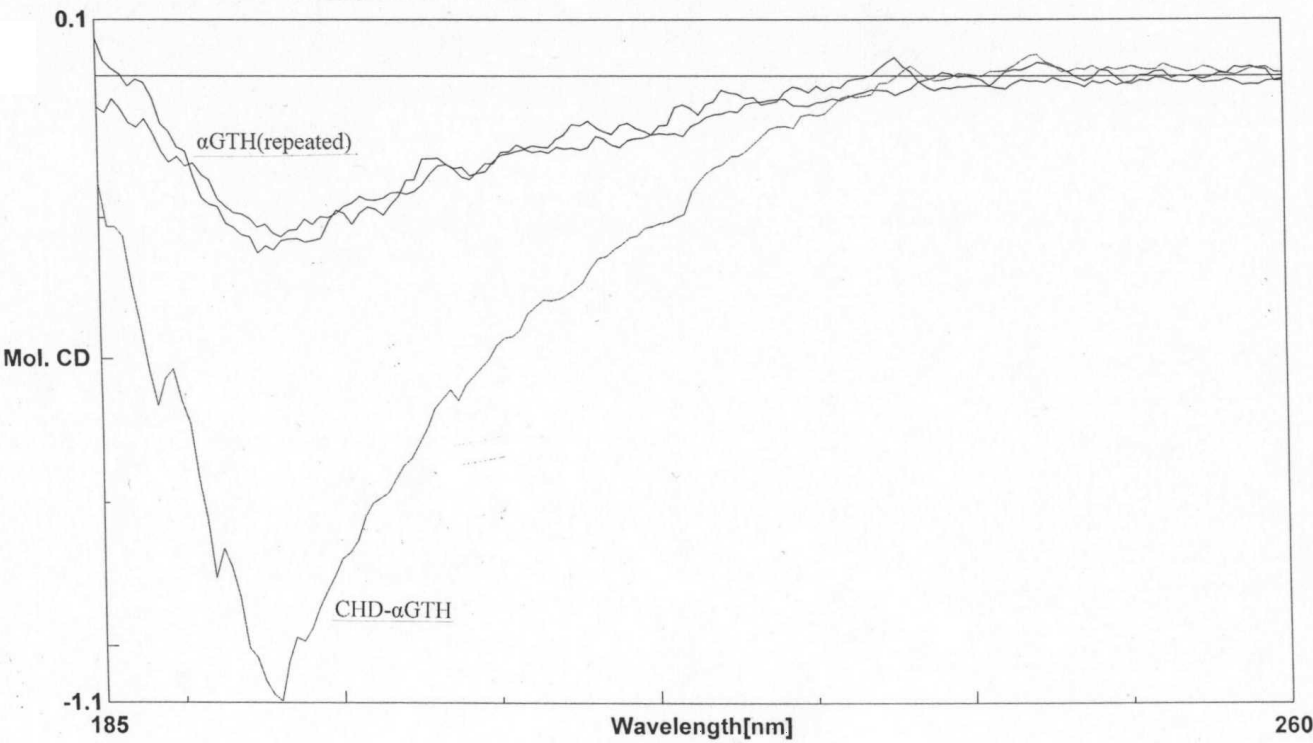

C

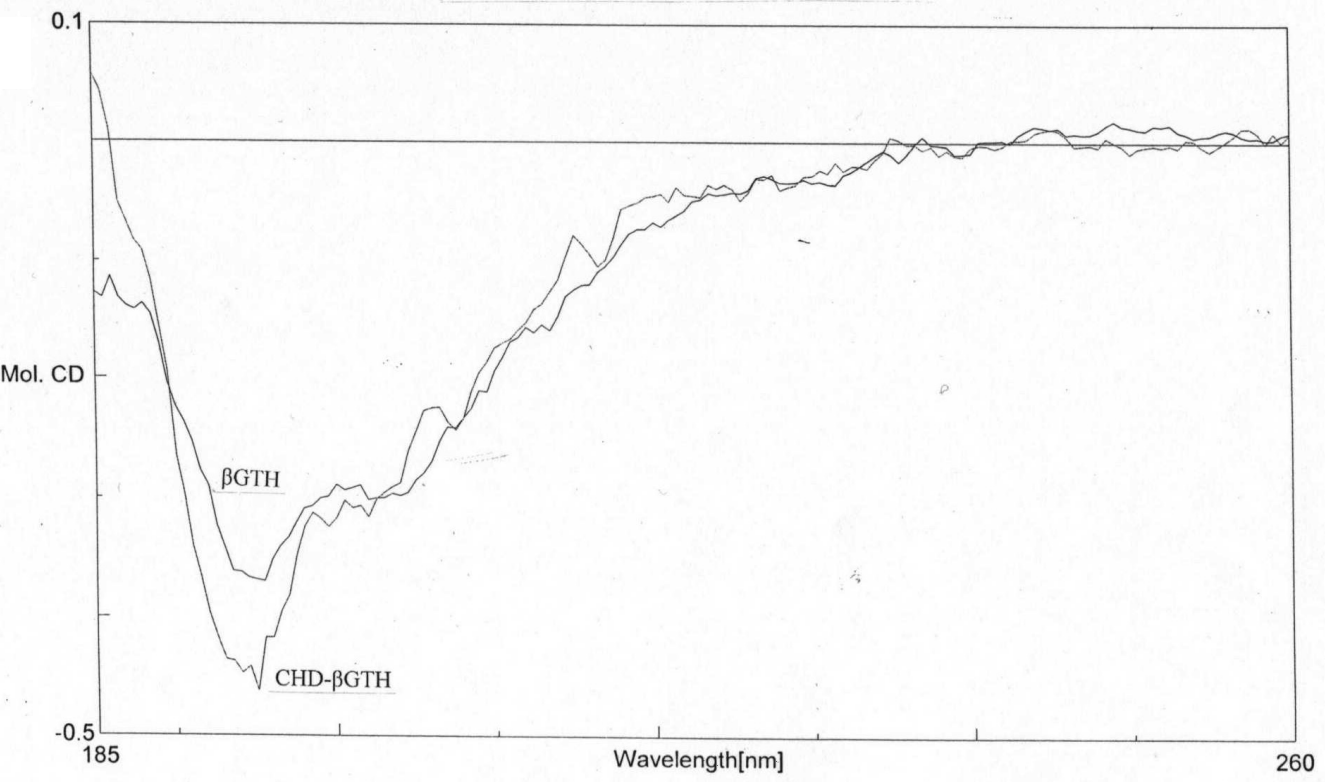

Fig. 1. Circular dichroism (CD) spectra of sturgeon GTH (A), $\alpha \mathrm{GTH}(\mathbf{B})$ and $\beta \mathrm{GTH}(\mathbf{C})$ standard and 1,2-cyclohexanedie (CHD)-modified preparations. 
Table 2

CONTENT OF SECONDARY STRUCTURE ELEMENTS (\%) OF INTACT AND Arg-MODIFIED GTH AND ITS SUBUNITS

\begin{tabular}{l|c|c|c|c}
\hline \multicolumn{1}{c}{ Preparation } & $\alpha^{*}$ & $\beta^{*}$ & $\beta_{\star}^{*}$ & $\mathrm{R}^{*}$ \\
\hline GTH & 2.7 & 38.3 & 19.8 & 39.1 \\
CHD-GTH & 2.8 & 39.6 & 19.6 & 37.9 \\
$\alpha$ GTH & 2.7 & 39.4 & 19.3 & 38.6 \\
CHD- $\alpha$ GTH & 2.5 & 36.7 & 18.3 & 42.5 \\
$\beta$ GTH & 2.8 & 40.3 & 19.5 & 37.5 \\
CHD- $\beta$ GTH & 3.4 & 33.3 & 16.8 & 46.0
\end{tabular}

CHD, modified with 1,2-cyclohexanedione; GTH, gonadotropic hormone; ${ }^{*} \alpha, \alpha$-helix; $\beta, \beta$-strand; $\beta$, $\beta$-turn; R, random coil; CHD, Arg-modified

The spatial structure of CHD-GTH seems to be different if compared to the standard GTH molecule. This is clearly seen in Fig. 1A, where the shape of the curve is significantly changed. The same can be said regarding the spectra of $\alpha \mathrm{GTH}$ and CHD- $\alpha \mathrm{GTH}$ (Fig. 1B). Spectral differences between $\beta \mathrm{GTH}$ and $\mathrm{CHD}-\beta \mathrm{GTH}$ were insignificant (Fig. 1C).

\section{DISCUSSION}

Modification of GTH and its separate subunits resulted in blockage of only one guanidine in each subunit and also two guanidines were blocked in the case of intact GTH. This provided evidence that each of the two guanidine groups, accessible for the reagent, is bound to an individual subunit and that both modified groups are located on the surface of the hormone dimeric molecule. The remaining four arginine residues - three in $\alpha$ and one in $\beta$ subunit are apparently encompassed with a hydrophobic environment, being buried inside the protein molecule and are inaccessible for the reagent.

The comparative immunologic investigation showed that the blockage of one guanidine group in any of the counterpart subunits (or in both subunits) did not prevent the formation of the hormone-like dimeric $\alpha-\beta$ structures recognizable by GTH antibodies (Table 1). Since the subunit self-reassociation or recombination requires structural fit of the interaction sites located on the counterpart subunits, it may be supposed that the modification with CHD did not produce any serious disturbances in the subunits spatial structure. Also, immunotests of the individual CHD-modified subunit showed full antigenic identity with the corresponding standards in the double immunodiffusion.

This indicated quite clearly that both subunits, despite of the modification, retained their native three-dimensional structure, or structural backbone of its functionally important zones, very close or identical with those of the native subunits. Immunoreactivity tests showed that CHD- $\alpha \mathrm{GTH}$ retained its initial activity while the reactivity of CHD- $\beta$ GTH slightly decreased (by 22\%) in comparison with that of the standard preparation (Table 1). Nevertheless, spectroscopic analysis revealed slight diferences between intact and CHD-modified $\alpha \mathrm{GTH}$ (Fig. 1B), which arose from the significant contributions of the $\beta$-structures, influenced by minor amount of $\alpha$-helix (Lees et al., 2006 ). In consequence, the modification of arginine in $\alpha \mathrm{GTH}$ caused shifts in the shape of curve and created certain distortions in its spatial structure, slightly increasing the content of the disordered or „random coil”" structures (Fig.1B, Table 2). In contrast, the modified $\beta G T H$ did not influence the shape of the curve and, consequently, the secondary structure of this subunit. It seems not to be influenced very much by the modification, but content of the disordered structure in the subunit slightly increased, while the amount of the regular structures somewhat decreased (Fig.1C, Table 2). This finding supports our earlier results indicating that the molecular coformation of sturgeon $\beta \mathrm{GTH}$, as a core of the dimer molecule, is much more rigid than that of the $\alpha \mathrm{GTH}$ (Зенкевич, 1992; Zenkevičs, 1994).

Using monovalent rabbit antiserum raised against standard GTH it was shown that the three types of hybrid $\alpha-\beta$ recombinants: $\mathrm{CHD}-\alpha \mathrm{GTH}+\beta \mathrm{GTH}, \alpha \mathrm{GTH}+\mathrm{CHD}-\beta \mathrm{GTH}$, and CHD- $\alpha \mathrm{GTH}+\mathrm{CHD}-\beta \mathrm{GTH}$, retained almost $60 \%$ of the original immunoreactivity typical for GTH and also revealed antigenic identity with the standard hormone. Antigenic identity of the hybrid dimers with reconstructed standard $\alpha \mathrm{GTH}+\beta \mathrm{GTH}$ and GTH was observed. The same immunoreactivity was shown by CHD-GTH (Table 1). CD spectra of GTH and CHD-GTH showed that the spatial structure of the modified hormone differed from that of the standard GTH (Fig. 1A). The above showed that the spatial structure of the antigenic determinant groups of the modified preparations retained their stereospecific complementarity with the active or combining sites of the antibodies raised against the standard hormone. This provided evidence that the three-dimensional structure of antigenic determinant groups of the hybrid dimers and CHD-GTH are related to that of the standard hormone and is recognisable by the active sites of its antibodies.

The investigation showed that the removal of one or two positively charged side groups, each in separate subunit, did not cause any considerable distortions neither in individual subunits nor in the standard hormone spatial structure, although some local changes occured in the content of particular types of the secondary structure (Table 2).

However, all modified dimer preparations completely lost hormonal activity, while still retaining rather high speciesspecific immunoreactivity, typical for the native hormone.

Regarding hormonal function, even minimal distortions of the spatial structure of protein- or peptide-like bioregulators like GTH may alter their active site functional (effector) group disposition on the molecular surface and result in considerable changes in their ability to interact stereospecifically with the hormone-specific receptor sites of the hormone-sensitive cell (oocyte) follicular membrane to induce the gonadotropic effects. The results of this investigation also support our previous findings indicating that the 
immunoreactivity of sturgeon GTH is much less vulnerable than its specific gonadotropic function (Зенкевич, 1992 ).

Based on these findings, we conclude that spatial structures of the intact and CHD-modified hormone preparations generally differ. They contain $2-3 \%$ of regular and distorted $\alpha$-helix, about $40 \% \beta$-strand, $20 \% \beta$-turn and a many „other structures" ( $40 \%)$ that can be considered as „random coil" (Table 2). This means that the modified guanidine groups did not play decisive role in sustaining the spatial structure of the individual subunits, i.e. modified subunits did not have considerable alterations in their secondary structure. They retained ability to interact complementary with the native and modified counterparts forming stable $\alpha-\beta$ structures with considerably lowered specific immunoreactivity.

Thus, the investigated guanidine groups are of exclusive importance for the sturgeon gonadotropin function at the hormone-specific receptor level, and probably are involved in the functionally important active sites or effector zones located on the surface of the hormone molecule. Also, the two investigated guanidine groups have some importance in the sustaining of the functionally effective three-dimensional structure of GTH subunits. Modification of the groups resulted in some shifts in particular types of the secondary structure producing changes in immunologic properties of the hormone.

\section{ACKNOWLEDGMENTS}

This work was supported by the Latvian Council of Science, grant 09.1550 .

\section{REFERENCES}

Hennen, G., Prusik, Z., Maghuin-Rogister, G. (1971). Porcine luteinizing hormone and its subunits. Eur. J. Biochem., 18, 376-383.
Lees, J.G., Miles, A.J., Wien, F., Wallace, B.A. (2006). A reference database for circular dichroism spectroscopy covering fold and secondary structure space. Bioinformatics, 22(16), 1955-1962.

Ouchterlony, O. (1958). Diffusion-in-gel methods for immunological analyses. Progr. Allergy, 5, 1-6.

Patty, L., Smith, E.L. (1975). Reversible modification of arginine residues Application to sequence studies by restriction of tryptic hydrolysis to lysine residues. J. Biol. Chem., 250(2), 557-564.

Sreerama, N., Venyaminov, S.Y., Woody, R.W. (1999). Estimation of the number of alpha-helical and beta-strand segments in proteins using circular dichroism spectroscopy. Protein Sci., 8, 370-380.

Thornton, V.F. (1971). A bioassay for progesterone and gonadotropins based on meiotic division of Xenopus oocytes in vitro. Gen. Comp. Endocrionl., 16, 599-605.

Whitmore, L., Wallace, B.A. (2004). DICHROWEB, an online server of protein secondary structure analyses from circular dichroism spectroscopic data. Nucleic Acid Res., 32, W668-W673.

Zenkevičs, H. (1994). Fish gonadotropic hormone: Structural-functional investigations. Proc. Latvian Acad. Sci., Section B, No. 5/6, 82-88.

Zenkevics, H., Klavins, M., Vose, V., Bucena, A. (2005). Humic acid reduces gonadotropin activity and hormonal sensitivity of frog oocytes. Aquatic Toxicol., 75, 380-383.

Zenkevics, H., Vose,V., Butsena, A. (2006). The key role of guanidine groups in the function of gonadotropin of the Russian sturgeon. Doklady Biochem. Biophys., 410, 278-279.

Зенкевич Г.А. (1992). Гонадотропный гормон рыб: получение и свойства [Fish Gonadotropic Hormone: Isolation and Properties]. Рига, Зинатне, 224 с. (in Russian).

Зенкевич Г.А., Арбатский Н.П., Сланке В.П., Желтова А.О., Деревицкая В.А. (1992). Структура углеводных цепей димерной молекулы и отдельных субъединиц гонадотропина русского осетра [Structure of the carbohydrate chains of the dimeric molecule and individual subunits of the Russian sturgeon gonadotropin]. Биоорганическая химия, 18, 226-234 (in Russian).

Зенкевич Г.А., Кирстукас И.П., Лаце 3.М., Сланке В.П. (1985). Сравнительное изучение свойств нативных и химически модифицированных субъединиц гонадотропного гормона осетра и севрюги [Comparative investigation of the native and chemically modified subunits of the Russian sturgeon and starred sturgeon gonadotropic hormone]. Известия АН СССР, Сер. биол., № 4, 598-603 (in Russian).

Received 26 August 2009

\section{ARGINĪNA RADIKĀḶU NOZĪME STORU GONADOTROPĪNA STRUKTŪRĀ UN FUNKCIJĀ}

Arginīna guanidīngrupas tika selektīvi k̦īmiski modificētas ar 1,2-cikloheksāndionu (CHD) gan stores (Acipenser güldenstädti Br.) gonadotropā hormona molekulā, gan tās $\alpha$ un $\beta$ subvienībās. No sešām hormona molekulā esošām guanidīngrupām tika modificētas divas, katra savā subvienībā. Noskaidrots, ka abas funkcionālās grupas atrodas molekulas virspusē. Reasociētie $\alpha-\beta$ dimēri, kas saturēja vienu vai abas CHD modificētas subvienības, neuzrādīja hormonam raksturīgo gonadotropo aktivitāti, lai gan to imūnreaktivitāte saglabājās visai augsta (57\%); šie hibrīddimēri arī izrādījās imunoloǵiski identiski ar standarthormonu. CD spektroskopijas datu analīze neuzrādīja krasas izmainas modificēto preparātu otrējā strukūrā, lai gan $\beta$ subvienībā nedaudz pieauga paralēlo un antiparalēlo $\beta$ struktūru saturs, kā arī palielinājās nesakārtotās struktūras (random coil) daḷ. Secināts, ka divām modificētajām guanidīngrupām ir izteikta loma hormonā kā pozitīvā lādiņa nesējām tā molekulārās struktūras funkcionāli nozīmīgās zonās, kas atbildīgas par gonadotropās funkcijas realizāciju membrānreceptoru līmenī. Modifikācija izsauca nobīdes hormona molekulārajā struktūrā - palielinājās telpiskās struktūras nesakārtotības pakāpe, kas ir saistāms gan ar hormonālās funkcijas zudumu, gan ar izmaiṇām imūnreaktivitātē. 